\title{
Cultured eastern oysters (Crassostrea virginica): retention and assimilation of picophytoplankton using a multi-biomarker approach
}

\author{
Rémi Sonier ${ }^{1,2,{ }^{*}}$, Réjean Tremblay $^{2}$, Frédéric Olivier ${ }^{3}$, Tarik Meziane ${ }^{3}$ and Luc André Comeau ${ }^{1}$ \\ ${ }^{1}$ Fisheries and Oceans Canada, Gulf Fisheries Centre, P.O. Box 5030, Science Branch, Moncton, NB E1C 9B6, Canada \\ 2 Institut des Sciences de la Mer, Université du Québec à Rimouski, 310 allée des Ursulines, C.P. 3300, Rimouski, \\ QC G5M 1L7, Canada \\ ${ }^{3}$ Unité Mixte de Recherche Biologie des organismes et écosystèmes aquatiques (BOREA UMR 7208), Sorbonne Université, \\ Muséum National d'Histoire Naturelle, Université Pierre et Marie Curie, Institut de Recherche pour le Développement, \\ Université de Caen-Normandie, Université des Antilles, 61 rue Buffon, 75005 Paris, France
}

Received 6 April 2017 / Accepted 1 August 2017

Handling Editor: François Le Loc'h

\begin{abstract}
In this study, we investigated the food sources of eastern oysters Crassostrea virginica cultivated in Atlantic Canada. Stable isotopes $\left({ }^{13} \mathrm{C}\right.$ and $\left.{ }^{15} \mathrm{~N}\right)$ and fatty acid biomarkers were used to identify these sources under in situ conditions for suspended $(\sim 0.5 \mathrm{~m}$ below surface $)$ and bottom $(\sim 2 \mathrm{~m})$ culture stocks. It was found that particulate organic matter represented the main food source, with major contributions from live phytoplankton. Higher lipid contents were detected in the digestive glands of suspended oysters compared to bottom oysters $(p<0.05)$. Bottom oysters did not show significant preference for detrital or bacterial organic matter. Near-surface waters contained an elevated picophytoplankton biomass (PPP, 0.2-2 $\mu \mathrm{m}$, $1.93 \pm 0.16 \mu \mathrm{gl}^{-1}$, mean $\pm \mathrm{SEM}$ ) compared to nanophytoplankton biomass (NPP, $>2 \mu \mathrm{m}, 1.05 \pm 0.15 \mu \mathrm{g} \mathrm{l}^{-1}$, mean \pm SEM). To determine whether the small size PPP was captured and assimilated by $C$. virginica, feeding trials were conducted in the laboratory using three PPP/NPP diets $(20 \%, 50 \%$, and $80 \%$ PPP), consisting of isotopically-labelled $\left(\delta^{13} \mathrm{C}\right)$ PPP cells (Nannochloropsis oculata) and non-labelled NPP cells (Tisochrysis lutea). An isotopically-labelled fatty acids analysis indicated PPP assimilation in various tissues (digestive gland, gills, mantle, and abductor muscle), including from oysters fed the reduced (20\%) PPP diet. Isotopic enrichment $\left({ }^{13} \mathrm{C}\right.$ ) in the FA 22:2 (non-methylene-interrupted or NMI) showed that precursors of NMIs utilized PPP carbon in its biosynthesis process. In conclusion, $C$. virginica assimilated primarily particulate organic matter (POM), including PPP, which dominated the phytoplankton community in near surface waters. C. virginica can exploit PPP carbon during fatty acid production and further biosynthesis.
\end{abstract}

Keywords: Crassostrea virginica / Picophytoplankton / Fatty acids / Stable isotopes / Aquaculture / Shellfish

\section{Introduction}

The Eastern oyster, Crassostrea virginica, has a broad latitudinal distribution along the Northwest Atlantic seaboard (Comeau, 2013). Suspension-feeding bivalves are important components of many coastal ecosystems; however, feeding pressure impacts plankton dynamics, biodeposition, and nutrient cycling (Prins et al., 1991). This said, shellfish aquaculture also provides important ecological services to the environment such benthic-pelagic coupling, creation of refuges for species from higher trophic levels and control

*Corresponding author: Remi.Sonier@dfo-mpo.gc.ca on suspended particles concentration (Coen et al., 2007). Recently, it has been demonstrated that bays with large rivers and high exchange with the open ocean will be more resilient under climate change when bivalve aquaculture is present (Filgueira et al., 2016). Bivalves primarily rely on naturally produced phytoplankton and other particulate organic matter as food sources (Trottet et al., 2008). Therefore, the filtration capacity of bivalves could effectively reduce seston concentrations (Guyondet et al., 2013), imposing strong control on phytoplankton assemblages at the base of the aquatic food chain (Prins et al., 1998; Cranford et al., 2009; Filgueira et al., $2014 b$ ). In conjunction with particle sorting before ingestion, the size and nutritional quality of food particles are two 
important factors explaining differences in filtration and retention capacities by bivalves (Barillé et al., 1997; Cresson et al., 2016). The retention efficiency (RE) of filter-feeders usually increases with particle size and may be species-specific (Møhlenberg and Riisgård, 1978; Ward and Shumway, 2004). Large particles can be captured with high efficiency, based on reported absolute efficiencies of $86-98 \%$ for $8-10 \mu \mathrm{m}$ particles for a variety of bivalves (Møhlenberg and Riisgård, 1978). In comparison, the retention of $1 \mu \mathrm{m}$ diameter particles is just 50\% (Shumway et al., 1985; Riisgård, 1988).

A multi-biomarkers approach, using stable isotopes and fatty acid (FAs) trophic marker methods, increases the potential to identify food sources from different origins (Perez et al., 2013). Stable isotopes analyses are widely used in food webs studies, food source reliance and trophic position estimation (Peterson and Fry, 1987; Gaillard et al., 2017) also as a tool to determine the contribution of various food items to a given organism diet (Fry, 2007). Since secondary consumers are enriched in ${ }^{13} \mathrm{C}$ and ${ }^{15} \mathrm{~N}$ relative to their food supply or prey, stable isotopes, such as carbon $\left(\delta^{13} \mathrm{C}\right)$ and nitrogen $\left(\delta^{15} \mathrm{~N}\right)$, are useful to determine the long-term assimilation of food (Peterson and Fry, 1987; Post, 2002). Because the relationships of these two isotopes differ with the origin of organic matter, measuring the isotopic ratios of the digestive gland of oysters allows the major contributing nutritional sources to be identified (Cresson et al., 2016). Prominent FA biomarkers of primary producers may be tracked within consumers, as they remain mostly unchanged through trophic pathways (Kelly and Scheibling, 2012). Omega-3 (w3) and omega-6 ( $\omega 6)$ poly-unsaturated FAs (PUFA) are synthesized almost exclusively by phytoplankton, macrophytes and plants (Dalsgaard et al., 2003) and phytoplankton community composition is a strong predictor of FAs content in nature (Lowe et al., 2014). In fact, it has been presented that divisions such Chlorophyta (green algae eukaryote), Dinophyta (dinoflagellate) and diatoms are rich in $\omega 3$ FAs with $31 \%, 40 \%$ and $17 \%$ respectively (Galloway and Winder, 2015). Some FAs are also attributed as dietary tracers for specific sources such as

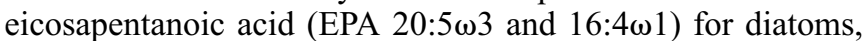

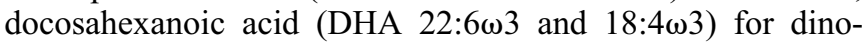
flagellates as well as numerous tracers for zooplankton $(20: 1 \omega 11,20: 1 \omega 9,22: 1 \omega 11,22: 1 \omega 9)$ and bacteria $(i-15: 0$, 15:0, $i$-17:0, 17:0) (Parrish, 2013; Gaillard et al., 2015). In bivalves, FAs from the digestive gland contribute to the storage of metabolic reserves, and may be profiled to obtain information on recent food ingestion (Perez et al., 2013).

The current study used stable isotopes and FAs' methods in parallel to provide information on the food sources of oysters cultured under different conditions: bottom and suspension. Most research on the trophic dynamics of oysters focuses on efficiently retained (80-100\%) autotrophic nanophytoplankton (NPP, 2-20 $\mu \mathrm{m}$ ) (Barillé et al., 1993; Ward and Shumway, 2004; Kach and Ward, 2008; Comeau, 2013), as higher biomass often leads to greater feeding activity by shellfish (Prins et al., 1998; Newell, 2004). To our knowledge, few studies have investigated how oyster culture is jointly impacted by phytoplankton biomass (quantitative) and diet composition (qualitative) (Pernet et al., 2012). Furthermore, most studies focus namely on Mytilus edulis (Trottet et al., 2008; Strohmeier et al., 2012) and Crassostrea gigas (Barillé et al., 1993, 1997) with little attention on the implications of smaller particles, such as picophytoplankton (PPP) cells which can reach high biomass in nutrient-rich estuaries under certain conditions (Richardson and Jackson, 2007; Kirkham et al., 2013). In the Gulf of St. Lawrence (Canada), numerous PPP species are present such as; Micromonas pusilla, Bathycoccus prasinos, Ostreococcus lucimarinus, Nannochloropsis sp., Picochlorum sp. and Aureococcus anophagefferens (Péquin et al., 2017). Thus, this present study aimed to: (1) assess the availability of size-fractioned phytoplankton (NPP and PPP) in the Foxley River system in Prince Edward Island (Canada); (2) identify the major food sources of cultured oysters (bottom vs. suspension); and (3) determine the potential of retention and assimilation of PPP cells by C. virginica. We tested two hypotheses, (1) bottom cultured oysters use more bacterial and microphytobenthos food compared to suspended cultured oysters and (2) PPP is the dominant food source in this oyster culture system, and is significantly ingested and assimilated by oysters.

\section{Material and methods}

\subsection{Field experiments}

\subsubsection{Phytoplankton biomass}

During the ice-free period (May to November 2014), water samples were collected (duplicates) twice a week from five sampling stations in Foxley River (Prince Edward Island, Canada), where oyster aquaculture is predominant (Fig. 1). This area is quite shallow (max depth $\sim 3 \mathrm{~m}$ ) and well mixed (no stratification). Water was collected at $1 \mathrm{~m}$ below the surface (5-1 Niskin ${ }^{\circledR}$ bottle). Size-fractioned phytoplankton biomass measurements were obtained by extracting chlorophyll- $a$ (henceforth chl-a). Sub-samples were filtered on $0.3 \mu \mathrm{m}$ $(50 \mathrm{ml})$ pore size glass fibre filters (GF75) to obtain total biomass $(>0.3 \mu \mathrm{m})$, and on $2 \mu \mathrm{m}(150 \mathrm{ml})$ a pore size polycarbonate filter $(25 \mathrm{~mm}$, GE Water and Process Technologies, Trevorse, $\left.P^{(\mathbb{R}}\right)$ for the NPP fraction $(>2 \mu \mathrm{m})$. The difference between these two size fractions yields PPP biomass $(0.3>2 \mu \mathrm{m})$. The filters were frozen directly in the field to $-40{ }^{\circ} \mathrm{C}$ (Stirling Ultracold portable freezer, Athens, $\mathrm{OH}$, USA), and were kept frozen until analysis. Chl- $a$ extractions were performed in $20-\mathrm{ml}$ scintillation vials with $10 \mathrm{ml}$ acetone (90\% final concentration) for a minimum of $24 \mathrm{~h}$ at $-40^{\circ} \mathrm{C}$. Final data were obtained using a bench top fluorometer (Trilogy ${ }^{\circledR}$, Turner Designs, Sunnyvale, CA) equipped with a chl- $a$ (with acidification) module.

\subsubsection{Stable isotopes}

To assess the isotopic signature of organic matter in the water column $(n=12)$, three sampling stations were established (Fig. 1) where the water samples were collected (1 m below sea-surface) in June, July, and August 2014. The samples (1-1) were filtered on GF/F filters (47 mm), dried for a 48 -h, and sent to an accredited laboratory facility to analyze (GG Harch Isotope Lab, Department of Earth Sciences, University of Ottawa, Canada) carbon $\left({ }^{13} \mathrm{C} /{ }^{12} \mathrm{C}\right)$ and nitrogen $\left({ }^{15} \mathrm{~N} /{ }^{14} \mathrm{~N}\right)$ stable isotopes. $\mathrm{GF} / \mathrm{F}$ filters were fumigated with $10 \% \mathrm{HCl}$ for $4 \mathrm{~h}$ to remove inorganic carbon. Samples and standards were weighed in tin capsules, and loaded into an elemental analyzer (Isotope Cube, Elementar, Germany) interfaced to an isotope ratio mass spectrometer. Separated gases were sent to an IRMS (interface 


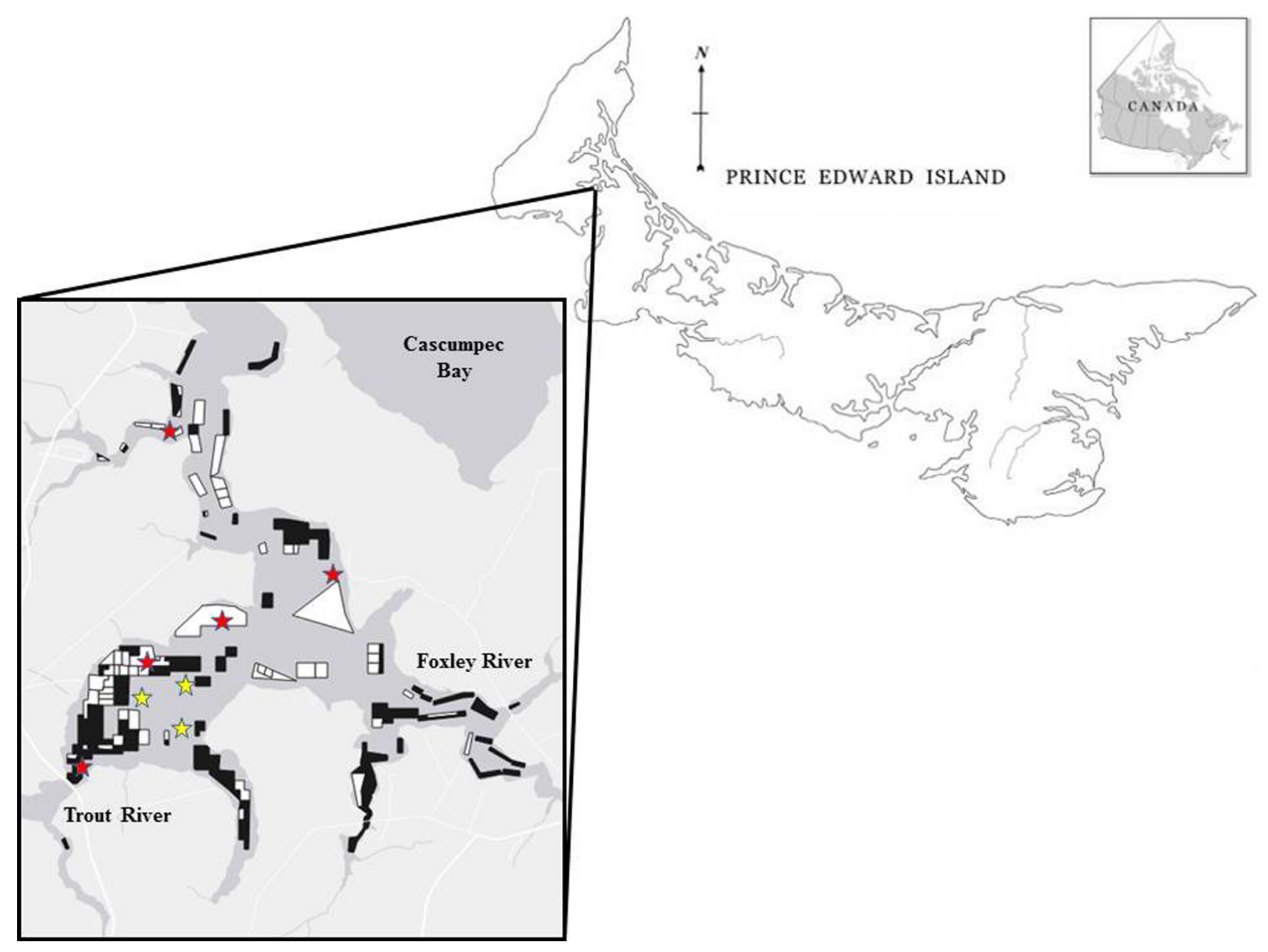

Fig. 1. Foxley River system in Prince Edward Island (Canada). Shellfish leases allocated for oyster (C. virginica) aquaculture are shown by polygons (white and black areas), in addition to sampling stations for phytoplankton biomass (red) and stable isotope (food sources and oysters) (yellow).

Conflo III with unit Delta Advantage, Thermo, Germany). The results are expressed in standard delta notation:

$$
\delta^{13} \mathrm{C} \text { or } \delta^{15} \mathrm{~N}=\left[\left(R_{\text {sample }} / R_{\text {standard }}\right)-1\right] \times 1000,
$$

where $R={ }^{15} \mathrm{~N} /{ }^{14} \mathrm{~N}$ or ${ }^{13} \mathrm{C} /{ }^{12} \mathrm{C}$ of the sample or standard (Peterson and Fry, 1987). All mean values or stable isotopes are expressed as mean \pm standard deviation (SD).

The isotopic signature $\left({ }^{13} \mathrm{C} /{ }^{12} \mathrm{C}\right.$ and $\left.{ }^{15} \mathrm{~N} /{ }^{14} \mathrm{~N}\right)$ of oyster tissues was determined at the end of July, from both the bottom $(n=40)$ and suspension $(n=40)$ cultures at the three sampling stations (Fig. 1). After dissecting half of the digestive gland from each bottom or suspended cultured oyster, it was frozen $\left(-80^{\circ} \mathrm{C}\right)$ in $4.5 \mathrm{ml}$ cryovial, fumigated with $10 \% \mathrm{HCl}$ for $4 \mathrm{~h}$ to remove inorganic carbon and sent for stable isotope analysis. The isotopic ratio $(R)$ values of the dried digestive glands from the $C$. virginica samples were determined by the methods developed at the IsoEnvironmental facility (Department of Botany, Rhodes University, Grahamstown, South Africa), using a Europa Scientific 20-20 IRMS interfaced to an ANCA SL Europa Analyser. All $\delta^{13} \mathrm{C}$ and $\delta^{15} \mathrm{~N}$ values were reported as \%o vs. Vienna PeeDeeBelemnite (VPDB) and air, respectively, and were normalized to internal standards calibrated to the International Atomic Energy reference materials (IAEA-CH6 for $\delta^{13} \mathrm{C}$ and IAEA-N2 for $\delta^{15} \mathrm{~N}$ ). Also samples of other potential food sources were collected by SCUBA divers and sent for analysis. Samples included macroalgae (Ulva sp.), marine plants (Zostera marina), and the first layer $(3 \mathrm{~mm})$ of sediment $(n=12)$ where oysters are bottom cultured.

\subsubsection{Fatty acids and lipid biomarkers}

Half of the digestive gland tissue from oysters from both cultured technique (bottom and suspended) were sampled at five time periods (June, beginning of July, end of July, August and September) for fatty acid (FAs) analysis. Each FAs data point consist of five digestive gland samples pooled together to assure sufficient material for proper extractions. Samples were freeze dried and ground to a homogeneous powder. Lipids were extracted using a modified Folch procedure as described in Parrish (1999). Fatty acid methyl esters (FAME) were prepared according to the method described by Lepage and Roy (1984) using sulfuric acid and methanol $(2: 98, \mathrm{v} / \mathrm{v})$ at 
Table 1. Common fatty acid (FA) biomarkers that were investigated and discussed in the present study.

\begin{tabular}{lll}
\hline Source & FATMs & References \\
\hline Diatoms & EPA, EPA/DHA $>1$, & Dalsgaard et al., 2003; Cabrol et al., 2015; \\
& $16: 1 \omega 7 / 16: 0>1$ & Gaillard et al., 2015 \\
Dinoflagellates & DHA, DHA/EPA $>1$ & Søreide et al., 2008; Kelly and Scheibling, 2012 \\
Picoeukaryotes & $16: 4 \omega 3+18: 3 \omega 3$ & Moynihan et al., 2016 \\
Zooplankton & $20: 1 \omega 9,20: 1 \omega 11,22: 1 \omega 9$ & Gaillard et al., 2015 \\
Terrestrial plants & $18: 2 \omega 6+18: 3 \omega 3>2.5$ & Budge and Parrish, 1998 \\
or seagrasses & $16: 1 \omega 7$, i15:0, 15:0, & Pernet et al., 2012; Parrish, 2013; Cabrol et al., 2015; \\
Detritus and bacteria & i17-0, 17:0 & Gaillard et al., 2017 \\
\hline
\end{tabular}

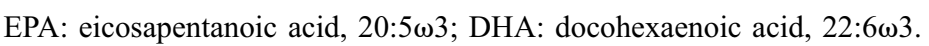

$100{ }^{\circ} \mathrm{C}$ for $10 \mathrm{~min}$, and were analyzed in the full scan mode (ionic range: $50-650 \mathrm{~m} / \mathrm{z}$ ) on a Polaris Q ion trap coupled to a multichannel gas chromatograph "Trace GC ultra" (Thermo Scientific) equipped with an autosampler model Triplus, a PTV injector, and a mass detector model ITQ900 (Thermo Scientific $\left.{ }^{\circledR}\right)$. The separation was performed with an Omegawax 250 (Supelco) capillary column with high purity helium as the carrier gas. Data were treated using Xcalibur v.2.1 software (Thermo Scientific ${ }^{\circledR}$ ). Methyl nonadecanoate (19:0) was used as an internal standard. FAME were identified by comparing retention times with known standards (Supelco 37 Component FAME Mix and menhaden oil; Supelco), and were further confirmed by mass spectrometry (Xcalibur v.2.1 software). In all samples, unknown peaks were identified according to their mass spectra, with emphasis on the FA trophic markers described in Table 1.

\subsection{Laboratory experiments}

\subsubsection{Retention efficiencies (RE)}

Adult oysters ( $n=15$, dried tissue mass $1.31 \pm 0.17 \mathrm{~g}$, mean \pm SD) were collected in February 2013 (water temperature of $-2{ }^{\circ} \mathrm{C}$ ), and were transferred to the marine station of the Institut des Sciences de la Mer de Rimouski (Pointe-au-Père, Québec, Canada). Equal numbers of oysters were placed in three 180-1 tanks with flow-through seawater (filtered through a $1 \mu \mathrm{m}$ filter and UV disinfected) and a gradually increasing temperature $\left(3^{\circ} \mathrm{C} /\right.$ day $)$ to reach $21^{\circ} \mathrm{C}$ for optimal filtration rates (based on Loosanoff, 1958). Oysters were acclimatized for one month and were fed daily with a 1:1:1 mixture (v/v/v) of Tisochrysis lutea (CCMP 1324), Diacronema lutheri (CCMP 459), and Chaetoceros neogracile (CCMP 1317) microalgae at a ratio of $5 \%$ oyster tissues dried mass. Algal strains originated from Bigelow National Center for Marine Algae and Microbiota (Maine, USA). Trials were conducted to assess the retention efficiency (RE) of each individual for targeted micro algal species. To assess the $\mathrm{RE}$ of $C$. virginica towards PPP cells $(<2 \mu \mathrm{m})$ in relation to different phytoplankton assemblages, three distinct regimes were used in a controlled environment. These regimes consisted of three different size fraction ratios: (1) 20:80, (2) 50:50, and (3) 80:20 between PPP and NPP (\%). Diets were adjusted at a total cell concentration equivalent in volume to 40 cells $\mu 1^{-1}$ of $T$. lutea, which corresponds to approximately $1.72 \times 10^{6} \mu \mathrm{m}^{-3} \mathrm{ml}^{-1}$. Cell counts were determined with a coulter counter (Z2
Beckman Coulter, California, USA) equipped with a $70 \mu \mathrm{m}$ aperture tube, with $0.1 \mathrm{ml}$ subsample being collected per reading. Algal species considered were Nannochloropsis oculata (PPP) (CCMP 525), a spherical unicellular flagellate of 1-2 $\mu \mathrm{m}$ in diameter and T. lutea (NPP), which is a golden brown flagellate with a spherical to pear shape of $3-5 \mu \mathrm{m}$ in diameter (Bigelow Laboratory for Ocean Sciences, Maine, USA). The species were batch-cultured in $\mathrm{f} / 2$ medium at $20^{\circ} \mathrm{C}$, under continuous illumination, in 20-1 carboys that was supplied continuously with $\mathrm{CO}_{2}$ to maintain a $\mathrm{pH}$ of $\sim 8$. Each oyster was acclimatized for $1 \mathrm{~h}$ in a 1.2-1 metabolic chamber with a circular stream of aeration along the chamber's wall to provide good water homogenization without promoting the resuspension of faeces and pseudo-faeces. After oysters were fed their respective experimental regime, subsamples were collected from each chamber every $15 \mathrm{~min}$ to assess cell depletion over time. Five oysters, or chambers, were allocated per experimental regime $(N=15)$. The retention efficiency (RE) was computed as presented in Comeau et al. (2015):

$$
\mathrm{RE}=\left[\left(C_{\text {control }}-C_{\text {live }}\right) / C_{\text {control }}\right] \times 100,
$$

where RE is percent retention efficiency of phytoplankton (PPP or NPP), $C_{\text {control }}$ is the phytoplankton counts (cells per $\mathrm{ml}$ ) in control chambers, and $C_{\text {live }}$ is the phytoplankton concentration (cells per $\mathrm{ml}$ ) in live specimen chambers.

\subsubsection{Refiltration factor (RF)}

Particular attention was given to the possibility that RE is positively related to the number of times the animal processed (filtered) the chamber volume during RE trials. Conceivably, an elevated RE might be attributable to an animal re-filtering the chamber volume numerous times, and accumulating PPP and NPP over time (Sonier et al., 2016). This artefact in the methodology would only amplify RE in trials where refiltration occurred. Available data were used to assess RE vs. the re-filtration factor (termed RF), which was calculated using the equation below (Comeau et al., 2015; Sonier et al., 2016):

$$
\mathrm{RF}=\left(\mathrm{Inc}_{\mathrm{T}} \times \mathrm{CR}_{\text {ind }} / 60\right) / V_{\mathrm{ch}},
$$

where Inc $_{\mathrm{T}}$ is the incubation time (min) in relation to the clearance rate $\left(1 \mathrm{~h}^{-1}\right)$ of individual oysters $\left(\mathrm{CR}_{\mathrm{ind}}\right)$ in each chamber. $V_{\text {ch }}$ is the volume of the chamber (l). $\mathrm{CR}_{\text {ind }}$ was measured using the indirect method described by 
Riisgård (1988), with water samples $(10 \mathrm{ml})$ being collected at 15 -min intervals. RF values are equivalent to the number of times that the entire volume of the chamber is filtered; $\mathrm{RF}>1$ confirms that the chamber was processed at least once before the end of the feeding trial. When RF values $>1$ were recorded, the relationship between RF and RE was further examined through regression analysis to determine whether $\mathrm{RF}$ effectively augmented RE. For $\mathrm{CR}_{\text {ind }}$ values, the first and last particle counts were omitted from the calculations to eliminate potential artefacts, such as changes in feeding behaviour due to the addition of food (experimental regimes) in each chamber or low particle counts at the end of incubation.

\subsubsection{Picophytoplankton assimilation}

PPP assimilation by oysters was conducted at a larger scale using bigger tanks (1801) with flow through natural sea water (28 ppt salinity, heated to $21^{\circ} \mathrm{C}$ ). Each feeding regime (treatment tanks) contained five oysters, for which the food supply was adjusted accordingly. For one week before the experiment, oysters were fed the three respective regimes (\%PPP:\%NPP of $20: 80,50: 50$, and $80: 20$ ) at a ratio of $5 \%$ of oyster tissue dry mass daily for acclimatization. The experimental trials involved three days of feeding, during which regular PPP cells $(N$. oculata) were substituted by isotopically labelled cells (with ${ }^{13} \mathrm{C}$ ). PPP was labelled using the protocol of Arnold et al. (2015), which involves supplementing the sea water medium with $1 \mathrm{mM}$ sodium $\left[{ }^{13} \mathrm{C}\right]$-bicarbonate $\left(\mathrm{NaH}^{13} \mathrm{CO}_{3}, 99 \%\right)$ (Cambridge Isotope Laboratories, MA, USA). The experiment ended after the oysters were subject to fasting for three complete days, to allow complete digestion and to purge the digestive system. Each oyster was dissected, and four tissue types were kept: (1) gills, (2) digestive gland, (3) mantle, and (4) abductor muscle. Each tissue was freeze-dried and homogenized using the classic glass mortar and pestle grinding method (sterilized between each sample with ethanol). Five grams of material for each tissue sample was weighed for hydrolysis $(100 \mu l \mathrm{KOH}$ $12.5 \%$ to the tissue sample) and subsequent fatty acids (FAs) extraction. In parallel, extraction from cultured and isotopically marked $N$. oculata algal stocks were obtained using direct hydrolyze combined with $50 \mu 1$ concentrated (centrifuged) algal suspension and $50 \mu \mathrm{KOH} 25 \%$. For both oyster tissues and algae solutions, the hydrolyzed mixture was then placed in a thermostat controlled dry-bath $\left(60^{\circ} \mathrm{C}\right)$ for $30 \mathrm{~min}$. Following hydrolysis incubation, $900 \mu$ l of extraction solvent $(1 / 315 \mathrm{mM}$ ammonium acetate and $2 / 3$ acetonitrile, $\mathrm{pH} 4$ ) was incorporated to the hydrolyzed solution and homogenized (vortex) for fatty acid extraction. Extracted samples were then centrifuged $(10000 \mathrm{rpm}, 3 \mathrm{~min})$ to purify lipid extracts by allowing residual proteins to sediment on the bottom of the Eppendorf. After centrifugation, $500 \mu \mathrm{l}$ of clear supernatant was collected and transferred to $5 \mathrm{ml}$ amber vials (with PVC septums) for fatty acid characterization. The analysis was performed using Continuous-flow Isotope Ratio Mass Spectrometry (CFIRMS) with a Deltaplus XP mass spectrometer (ThermoScientific) coupled to an elemental analysis (EA) COSTECH 4010 (Costech Analytical). Analytical error $(n=50)$ of the measurements was $0.2 \%$ and $0.4 \%$ for $\delta^{15} \mathrm{~N}$ and $\delta^{13} \mathrm{C}$, respectively. System suitability was evaluated before analysis using a standard deviation of zero reference gas (nitrogen and carbon dioxide) over 10 measurements. Maximum acceptable variation was set to $0.06 \%$. For each analysis sequence, 10 secondary standards were used to calibrate the obtained values. The certified sediment standard (MicroElemental analysis) had reference values of -4.40 and -26.10 for $\delta^{15} \mathrm{~N}$ and $\delta^{13} \mathrm{C}$, respectively. The two mobile phases consisted of (A) $10 \mathrm{mM}$ ammonium acetate and (B) $0.01 \%$ acetic acid in acetonitrile $(\mathrm{ACN})$. The ingestion and assimilation of PPP by $C$. virginica were estimated using mass spectrometry outputs. More specifically, the enrichment in ${ }^{13} \mathrm{C}$ of specific fatty acids from different food regimes containing isotopically $\left(\delta^{13} \mathrm{C}\right)$ marked PPP. Four fatty acids were considered: (1) 20:5 33 (EPA), which is a dominant fatty acid in the composition of $N$. oculata (Seychelles et al., 2009), (2) 22:6 33 (DHA), which is a dominant fatty acid in T. lutea (then Isochrysis galbana) (Seychelles et al., 2009), (3) 20:1, a precursor for NMI and usually synthetized by the organism and are absent in algae used in feeding trials (Zhukova, 1991; Da Costa et al., 2015) and (4) 22:2 (Zhukova and Svetashev, 1986) typical for most bivalves.

\subsection{Statistical analysis}

The relationship between size fraction (PPP and NPP) biomass over time was tested for autocorrelation and heterogeneity using the "gls" function (library-nlme) in the $\mathrm{R}$ environment (version 3.0.1, R Core Team, 2013). Pearson's correlation tests were used to detect correlations between time series. Linear analysis of covariance (ANCOVA) was performed using the "lm" function with one covariate in the $\mathrm{R}$ environment. ANCOVA outputs were presented textually (likelihood ratio test $=\mathrm{LRT}$, df, $p$ values), and as correlation coefficients $(\rho)$. For the comparison of FA profiles, distancebased permutational multivariate analysis of variance was used to compare multivariate variables between oysters from the two culture methods. The assumption of homoscedasticity was verified with a PERMDISP test, no data transformations were needed, and then a PERMANOVA (9999 permutations) was performed. A posteriori comparisons were completed using a PERMANOVA pairwise test. To analyze the similarity between profiles, SIMPER (SIMilarity PERcentages) procedures were used to identify variables responsible for dissimilarities (PRIMER ${ }^{\circledR} 6$ software module and PERMANOVA 1.02). Multivariate analyses were performed with PRIMER $^{\circledR} 6$ software and univariate tests using $\mathrm{R}$ software (version 3.0.1, R Core Team, 2013). The linear regression analyses was used to evaluate the effect of RE on RF. Differences between culture methods (bottom vs. surface) for stable isotopes data $\left(\delta^{13} \mathrm{C}\right.$ and $\left.\delta^{15} \mathrm{~N}\right)$ were tested using two samples $t$-tests, with single-factor ANOVAs being used to assess how sampling dates impacted the time series results.

\section{Results}

\subsection{Phytoplankton biomass}

Phytoplankton fractioned (NPP and PPP) biomass (chl- $a$ $\mu \mathrm{gl}^{-1}$ ) (Fig. 2) showed autocorrelation $(\rho=0.49)$ and a significant interaction between phytoplankton size and sampling date $(\mathrm{LRT}=8.01, \mathrm{df}=1, p<0.001)$. Both NPP and PPP biomass significantly changed over time (one-way 


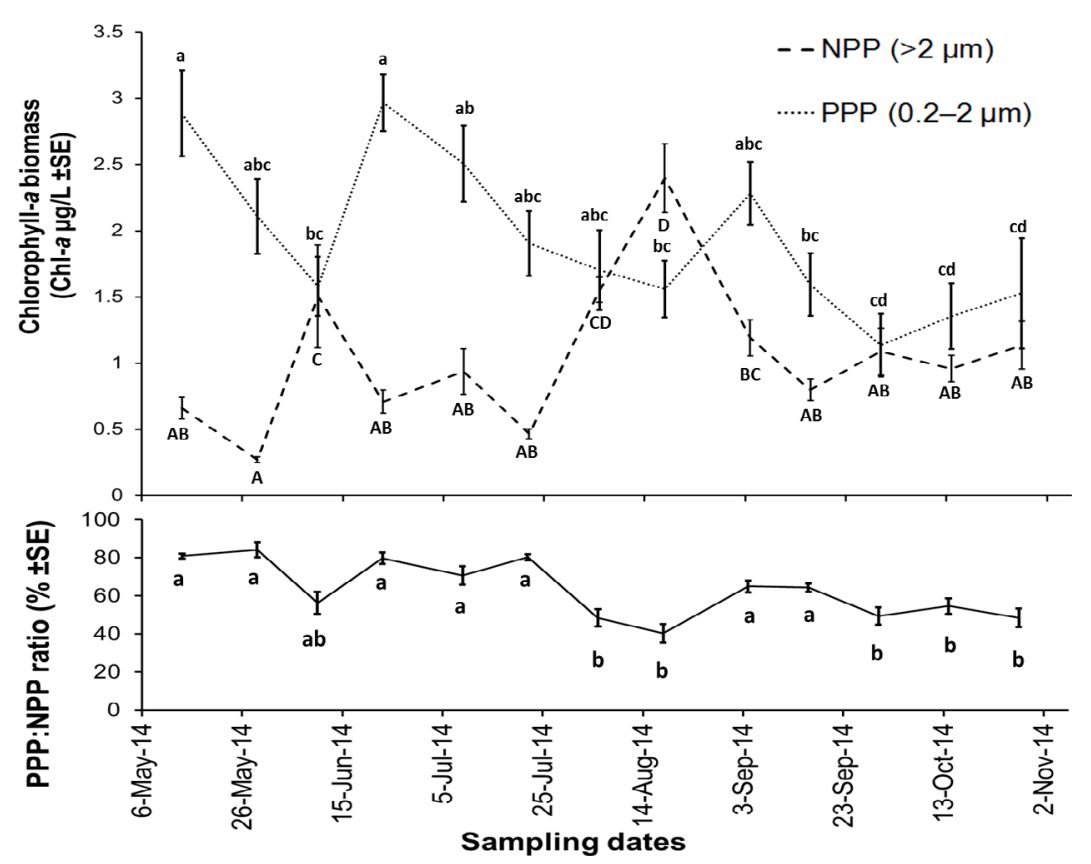

Fig. 2. Size-fractioned phytoplankton biomass (average \pm SE, averaged from seven sampling stations, in duplicates) including PPP ratio (average $\% \pm \mathrm{SE}$ ) in Foxley River $(\mathrm{PEI})$. Tukey posteriori tests results $(p<0.001)$ are presented, with different letters representing significant differences, NPP (uppercase) and PPP (lowercase).

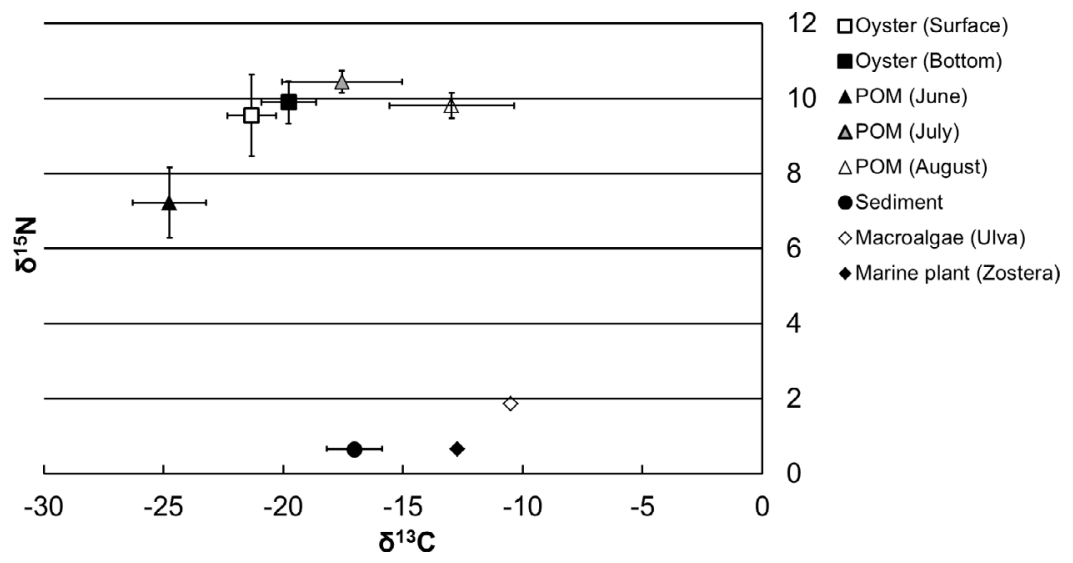

Fig. 3. Mean (\%o \pm standard deviation) $\delta{ }^{13} \mathrm{C}$ and $\delta^{15} \mathrm{~N}$ of the digestive glands from surface $(n=40)$ and bottom $(n=40)$ cultured oysters (C. virginica), in addition to the $\delta^{13} \mathrm{C}$ and $\delta^{15} \mathrm{~N}$ from different sources: POM $(n=12)$, sediment $(n=12)$, a macroalgae (Ulva sp.) $(n=1)$, and a marine plant (Zostera marina) $(n=1)$.

ANOVA, $\mathrm{df}=12, p<0.0001)$. Differences between size classes (Tukey posteriori tests, $p<0.05$ ) were attributed to the lower biomass of NPP in late-May and peaks in mid-June and at the end of August. In comparison, PPP biomass had significant peaks in mid-May and late-June, with low concentrations in mid-June and September to November (fall) (Fig. 2). Sub-surface water samples showed that PPP $\left(1.93 \pm 0.16 \mu \mathrm{g} \mathrm{l}^{-1}\right)$ biomass was significantly higher compared to NPP $\left(1.05 \pm 0.15 \mu \mathrm{gl}^{-1}\right)$ biomass $(p<0.001)$. The PPP:NPP biomass ratio (\%) ranged between 44 and $89 \%$, and was significantly different between sampling dates $(\mathrm{df}=12$, $p<0.0001$ ) (Fig. 2). Significantly lower ratios of PPP were observed in mid-August and September to November (fall) (Tukey posteriori tests, $p<0.05$ ).

\subsection{Stable isotopes}

In June, July, and August 2014, surface water POM $\delta^{13} \mathrm{C}$ and $\delta^{15} \mathrm{~N}$ values ranged between $-24.75 \pm 1.53 \%$ and $-12.96 \pm 2.60 \%$ o, and $7.23 \pm 0.94 \%$ o and $10.44 \pm 0.29 \%$, respectively (Fig. 3). A significant difference (two-sample $t$-test, $t=-6.38, p<0.001, n=40)$ the between $\delta^{13} \mathrm{C}$ ratios of suspended cultured oysters $(-21.32 \pm 1.02 \%$ ) and bottom cultured oysters $(-19.78 \pm 1.14 \%)$ was obtained, whilst no difference was found between $\delta^{15} \mathrm{~N}$ ratios $(9.90 \% 0 \pm 0.56$ and $9.55 \% \pm 1.08$, respectively, $n=40$ ) (Fig. 3). Oysters' shell length (mean $\pm \mathrm{SD})$ was similar at $74.9 \pm 7.2 \mathrm{~mm}$ and $70.1 \pm 7.7 \mathrm{~mm}$ for bottom and suspension cultured oysters respectively. Regardless of the culture method used 
C. virginica mostly fed on POM where the nitrogen $\left(\delta^{15} \mathrm{~N}\right)$ values of oysters sampled in July were closely related to water POM sampled in June, with a typical enrichment of 2-4\%o (Peterson and Fry, 1987; Post, 2002) between the primary consumer and its diet (Fig. 3). However, $\delta^{15} \mathrm{~N}$ enrichment results $>4 \%$ also indicated that the sediments, macroalgae (Ulva sp.), and marine plants (Z. marina) were not detected as suitable food inputs in cultured oysters from our system.

\subsection{Fatty acids and lipid biomarkers}

Total FA concentration in the digestive glands of oysters was significantly affected by sampling dates (pseudo- $F=3.73$, $\mathrm{df}=4, p<0.01$ ) and culture methods (pseudo- $F=3.86, \mathrm{df}=1$, $p<0.05$ ) without interaction (pseudo- $F=0.61, \mathrm{df}=4$, $p>0.05$ ) between these two factors (Tab. 2) (PERMANOVA analyses). Thus, oysters cultured in suspension accumulate more fatty acids in their digestive glands compared to bottom cultured oysters. Total FA concentration was significantly lower in July compared to all other months (pair-wise tests on sampling dates, $p<0.05$ ) (Tab. 2). FA composition $(\%)$ (Tab. 2) differed significantly in relation to sampling date (pseudo- $F=9.14, \mathrm{df}=4, \quad p<0.001$ ) and culture method (bottom vs. suspension) (pseudo- $F=2.76, \mathrm{df}=1, p<0.05$ ), without any interactions between the two factors (pseudo$F=0.70, \mathrm{df}=4, p=0.88$ ) (PERMANOVA analyses). Pairwise test results showed significant differences between all sampling dates $(p<0.05, \mathrm{df}=12)$ and culture methods $(p<0.05, \mathrm{df}=30)$. The $7 \%$ depletion (Tab. 2) of EPA $(20: 5 \omega 3)$ contributed to most $(16 \%)$ of the dissimilarity between sampling dates. In August and September, EPA levels returned to similar levels as June. Regardless of the culture method used, specific FA contribution was similar in June, August, and September. Statistically discrepancies (SIMPER analyses with Bray Curtis similarity, pooled data from all sampling stations) between culture methods were mainly explained by microalgal biomarkers (Tab. 2) in bottom cultured oysters, which were represented by slightly superior values of EPA and inferior values of DHA, explaining $11.4 \%$ and $8.5 \%$ of differences, respectively. However, biologically interpreting EPA and DHA as proxies our results suggest that oysters fed more on dinoflagellates (DHA/EPA $>1)$, with a marked input in late July when DHA levels significantly increased. The opposite is apparent in the fall (September) where diatoms biomarker (EPA/DHA $>1)$ is predominant. Even though less important than dinoflagellates, diatoms might represent a minimal food source, especially in early June and late September, due to increasing EPA values. Detritus and bacteria biomarkers $(16: 1 \omega 7,15: 0,15: 0 i+a i, 17: 0,17: 0 i+a i)$ did not present differences between bottom vs. suspension cultured oysters. Food sources derived from terrestrial plants or seagrasses are shown as contributing to the diet of oysters $(18: 2 \omega 6+18: 3 \omega 3>2.5)$ independent of the culture method used.

\subsection{Retention efficiency (RE) and refiltration factor (RF)}

Crassostrea virginica exhibited significantly different $\mathrm{RE}$ values for PPP and NPP (two-sample $t$-test $=2.26, p<0.001$, $\mathrm{df}=9)$. RE was significantly higher $(p<0.05)$ in PPP cells
$(92.1 \pm 2.7 \%)$ for oysters in the regime with the lowest concentration (20\%) of $N$. oculata cells (Tab. 3). Inversely, the lowest RE $(71.8 \pm 8.2 \%)$ was associated with PPP from the regime with the highest $(80 \%)$ concentration of $N$. oculata. RE values in NPP were not significantly different between experimental regimes, and averaged between $92.9 \pm 6.9 \%$ and $99.1 \pm 1.0 \%$ (Tab. 3 ). For all RE trials ( $1 \mathrm{~h}$ incubation time with experimental food regimes), all $\mathrm{RF}$ values were $\leq 1$, indicating that individual oysters did not have the opportunity to refilter the whole chamber's volume (1.251). No further regression analysis was needed based on confidence that RE values were not overestimated by refiltration.

\subsection{Picophytoplankton assimilation}

The polyunsaturated fatty acid EPA was naturally present at high concentrations in $N$. oculata $(22.7 \pm 1.58 \%)$, whereas DHA was the dominant FA in T. lutea (Tab. 4). The results of the enrichment trials (labelled regimes) against the controls (unlabelled regimes) confirmed that PPP was assimilated in the tissues of $C$. virginica, especially for 20:1, EPA, 22:2 (NMI), and DHA (Tab. 5). The most abundant FA present in oysters was EPA from the labelled PPP species. This FA showed isotopic $\left({ }^{13} \mathrm{C}\right)$ enrichment in oyster tissues. This FA was particularly detected in the digestive gland, confirming the ingestion of PPP cells. Bivalves have no, or very limited, capacity to biosynthesize EPA and DHA. Therefore, the ${ }^{13} \mathrm{C}$ enrichment of EPA in certain organs (such as gills, mantle, and abductor muscle) suggests that PPP was assimilated, with carbon subsequently being transferred to other tissues. The lack of DHA isotopic enrichment, which was highly abundant in the NPP species (T. lutea) (Tab. 4), confirmed that ${ }^{13} \mathrm{C}$ enrichment in oysters (Tab. 5) originated solely from the ingestion of labelled PPP cells. Enrichment of 22:2 (NMI) was also detected using 20:1 as a precursor.

\section{Discussion}

Using stable isotopes, we demonstrated that the main food sources of farmed oysters, regardless of culture methods, are particulate organic matter (POM) with no apparent contribution from sediments (which could include microphytbenthos), a green macroalgae (Ulva sp.) and a seagrass (Z. marina). This said, future studies should consider further extensive surveys of food sources such as the potential implication of microphytobenthos (MPB) to benthic filter feeders communities. The MPB is characterized by high spatial variability at microscale (Spilmont et al., 2011) with fairly stable biofilms at a large scale in estuaries (Brito et al., 2013). Those general isotopic results are in agreement with numerous studies on oyster's food sources discrimination (Pernet et al., 2012; Moynihan et al., 2016). Stable isotopes analysis can provide time-integrated information (long term) on food sources, averaging the natural environment variability in dietary components (Pernet et al., 2012). Whereas FAs are incorporated largely unaltered into the lipid reserves of the primary consumers (like oysters) generally reflecting the FA profiles of the food consumed (short term) (Dalsgaard et al., 2003). Our FA biomarkers results indicated that dinoflagellates (DHA or DHA/EPA > 1) may be considered a main food source, with no 


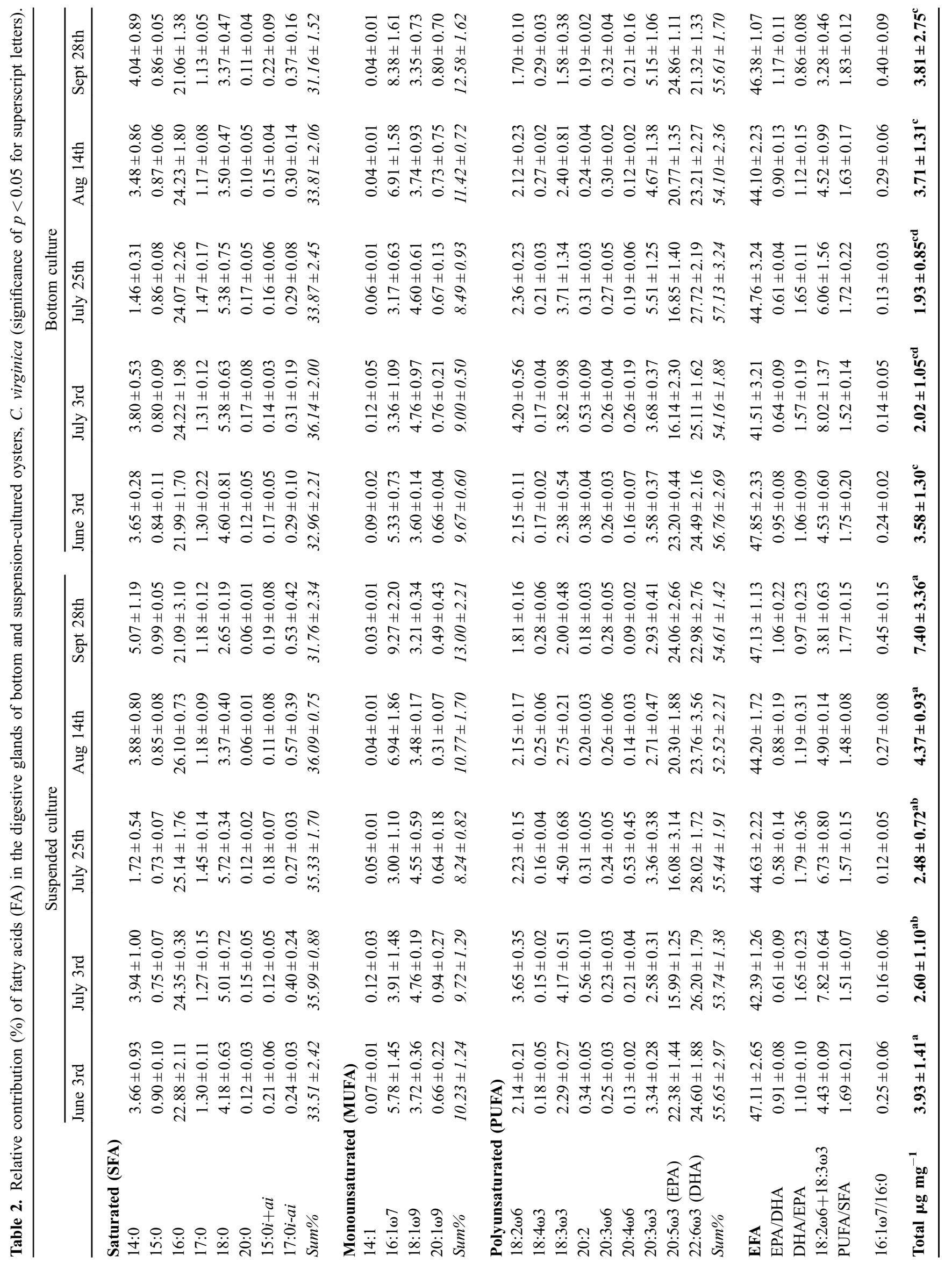


Table 3. Retention efficiencies of $C$. virginica (mean $\% \pm \mathrm{SD}$ ) on PPP (Nannochloropsis occulata) and NPP (Tisochrysis lutea) in relation to the three experimental regimes (\%PPP: \%NPP ratios). Two significantly different values are shown in bold.

\begin{tabular}{lll}
\hline Regime ratios & \multicolumn{2}{c}{ Retention efficiency (\%) } \\
\cline { 2 - 3 } & PPP $(N$. oculata $)$ & NPP (T. lutea) \\
\hline (1) $20: 80$ & $\mathbf{9 2 . 1} \pm \mathbf{2 . 7 *}$ & $99.1 \pm 1.0$ \\
(2) $50: 50$ & $74.2 \pm 12.8$ & $92.9 \pm 6.9$ \\
(3) $80: 20$ & $\mathbf{7 1 . 8} \pm \mathbf{8 . 2 *}$ & $93.6 \pm 6.1$ \\
\hline
\end{tabular}

${ }^{*} p$ value $<0.05$

significant discrepancies between bottom and suspension cultured oysters while diatoms (EPA or EPA/DHA $>1$ ) may contribute minimally to cultured oysters diet. Also, high DHA/EPA ratio in July seems to also correspond to an increase in PPP biomass as well, which may translate to important dinoflagellates numbers in the PPP communities. This said, other diatoms biomarker may be used such as $(16: 1 \omega 7 / 16: 0)$ $>1$, and from our results indicating no evident contribution from diatoms in the oysters diets with low ratios ranging from $0.12 \pm 0.05$ to $0.45 \pm 0.15$. Although not statistically significant, superior EPA contribution can be observed in bottom cultured oysters compared to their suspension-cultured counterparts. This small discrepancy might arise from microphytobenthos found normally in the first millimetres of sediment and includes numerous unicellular phototrophic microorganisms dominated by marine diatoms (up to $95 \%$ ) (Cognie et al., 2001). In estuaries, such as the Foxley system, microphytobenthos could easily be resuspended by tidal currents which reach up to $20 \mathrm{~cm} / \mathrm{s}$; thus, contribute to the food supply of filter-feeders (Underwood and Kromkamp, 1999). However, it is noteworthy to mention that only our FAs profiles suggest a potential microphytobenthos/diatoms interaction whereas bulk isotopic results showed no contribution of sediment-derived material in the oyster's diet. Similar discrepancies between analytical methods were observed where FAs profiles suggested that terrestrial plants may contribute to the oyster's diet due to the presence of $18: 2 \omega 6+18: 3 \omega 3>2.5$ in their tissues (Budge and Parrish, 1998) since terrestrial plants (as well as their respective pollen) contain large amounts of those two FAs (Ackman, 1986; Parrish et al., 1995). This relation could not be captured using solely our stable isotopes analyses with the seagrass, $Z$. marina which is a marine plant. Using FAs and stable isotopes analyses to assess the nutritional value of vascular plants for bivalves has been explored extensively and recent studies presented macroalgae as a marginal contributor to diet of the bivalve Astarte elliptica (Gaillard et al., 2017) and Venus verrucosa (Perez et al., 2013). However, not exclusive to plants and seagrass species, 18:3 33 is also present in some picoeukaryotic prasinophytes (Chlorophyta) (Dalsgaard et al., 2003; Moynihan et al., 2016) and is sometimes significantly correlated with dinoflagellates abundance (Lowe et al., 2014). Overall, techniques that assess both long term (stable isotopes) and recent (FAs profiles of the digestive glands) food assimilation by bivalves should be used together because detection thresholds might differ for the same food source.
Table 4. Lipid composition ( $\%$ of total lipid classes, $\%$ of specific fatty acids) of fresh PPP (Nannochloropsis oculata) and NPP (Tisochrysis lutea) in relation to total dried weight. Null contribution is represented by a blank data cell.

\begin{tabular}{|c|c|c|}
\hline & Nannochloropsis oculata & Tisochrysis lutea \\
\hline \multicolumn{3}{|l|}{ Saturated (SFA) } \\
\hline $14: 0$ & $\mathbf{0 . 2 4} \pm 0.12$ & $18.75 \pm 3.13$ \\
\hline $15: 0$ & $0.57 \pm 0.03$ & $0.62 \pm 0.03$ \\
\hline $16: 0$ & $\mathbf{3 4 . 7 6} \pm 1.50$ & $\mathbf{2 0 . 5} \pm 0.81$ \\
\hline 17:0 & & $0.61 \pm 0.07$ \\
\hline 18:0 & $0.15 \pm 0.17$ & $3.00 \pm 0.39$ \\
\hline $20: 0$ & $0.22 \pm 0.02$ & $0.81 \pm 0.29$ \\
\hline $21: 0$ & $0.10 \pm 0.01$ & $0.15 \pm 0.30$ \\
\hline $22: 0$ & & $1.46 \pm 0.62$ \\
\hline $24: 0$ & & $1.13 \pm 0.48$ \\
\hline Sum $\%$ & $36.04 \pm 1.54$ & $47.03 \pm 2.79$ \\
\hline \multicolumn{3}{|c|}{ Monounsaturated (MUFA) } \\
\hline $14: 1$ & $0.18 \pm 0.09$ & $0.55 \pm 0.11$ \\
\hline \multicolumn{3}{|l|}{$15: 1$} \\
\hline $16: 1 \omega 7$ & $\mathbf{3 0 . 7 2} \pm 1.39$ & $\mathbf{9 . 1 2} \pm 2.48$ \\
\hline $17: 1$ & & $0.81 \pm 0.11$ \\
\hline $18: 1 \omega 9$ & $\mathbf{3 . 1 2} \pm 1.04$ & $\mathbf{1 0 . 4 3} \pm 6.98$ \\
\hline $20: 1$ & $0.09 \pm 0.02$ & $0.81 \pm 0.18$ \\
\hline Sum $\%$ & $34.11 \pm 1.85$ & $21.74 \pm 4.99$ \\
\hline \multicolumn{3}{|c|}{ Polyunsaturated (PUFA) } \\
\hline $18: 3 \omega 3$ & $0.18 \pm 0.02$ & $4.49 \pm 1.73$ \\
\hline $18: 3 \omega 6$ & $0.22 \pm 0.01$ & $1.22 \pm 0.82$ \\
\hline \multicolumn{3}{|l|}{$18: 4 \omega 3$} \\
\hline $18: 2 \omega 6$ & $3.07 \pm 0.19$ & $2.38 \pm 2.79$ \\
\hline $20: 4 \omega 6$ & $3.10 \pm 0.92$ & $0.93 \pm 0.16$ \\
\hline $20: 5 \omega 3$ (EPA) & $22.71 \pm 1.58$ & $\mathbf{5 . 3 8} \pm 1.09$ \\
\hline $20: 3 \omega 6$ & $0.50 \pm 0.04$ & \\
\hline $20: 3 \omega 3$ & & $0.76 \pm 0.24$ \\
\hline 22:6 $\omega 3$ (DHA) & & $14.17 \pm 1.71$ \\
\hline $22: 2$ & $0.06 \pm 0.09$ & \\
\hline $22: 5 \omega 3$ & $1.90 \pm 0.07$ & \\
\hline Sum\% & $29.84 \pm 2.25$ & $31.23 \pm 2.48$ \\
\hline
\end{tabular}

Phytoplankton biomass in the Foxley River system is very variable, with PPP being a major contributor to total phytoplankton biomass of this oyster culture area. Based on Comeau (2013), even though calculations do not take into account natural oyster reefs, this system does not exert a dominant top-down control on phytoplankton abundance in relation to the abundance of cultured bivalves. The present study showed that oysters cultured in suspension had higher fat content compared to those cultured on the bottom. This outcome may be attributed to different parameters such as enhanced food fluxes at the surface layer, important primary production in the photic layer, and high surface temperatures. However, Comeau (2013) showed that the grazing ability (clearance rates) of oysters, assessed by the surface of gills per unit of dry tissue, is lower for suspended cultured oysters. Such 
Table 5. Results $\left(\%{ }^{13} \mathrm{C}\right)$ for specific fatty acids of $C$. virginica tissues (gills, digestive gland $=\mathrm{DG}$, mantle, and abductor muscle $\left.=\mathrm{AM}\right)$ from regimes with different PPP/NPP ratios. Bold numbers represent enrichment in ${ }^{13} \mathrm{C}$ compared to the unlabelled regime (control).

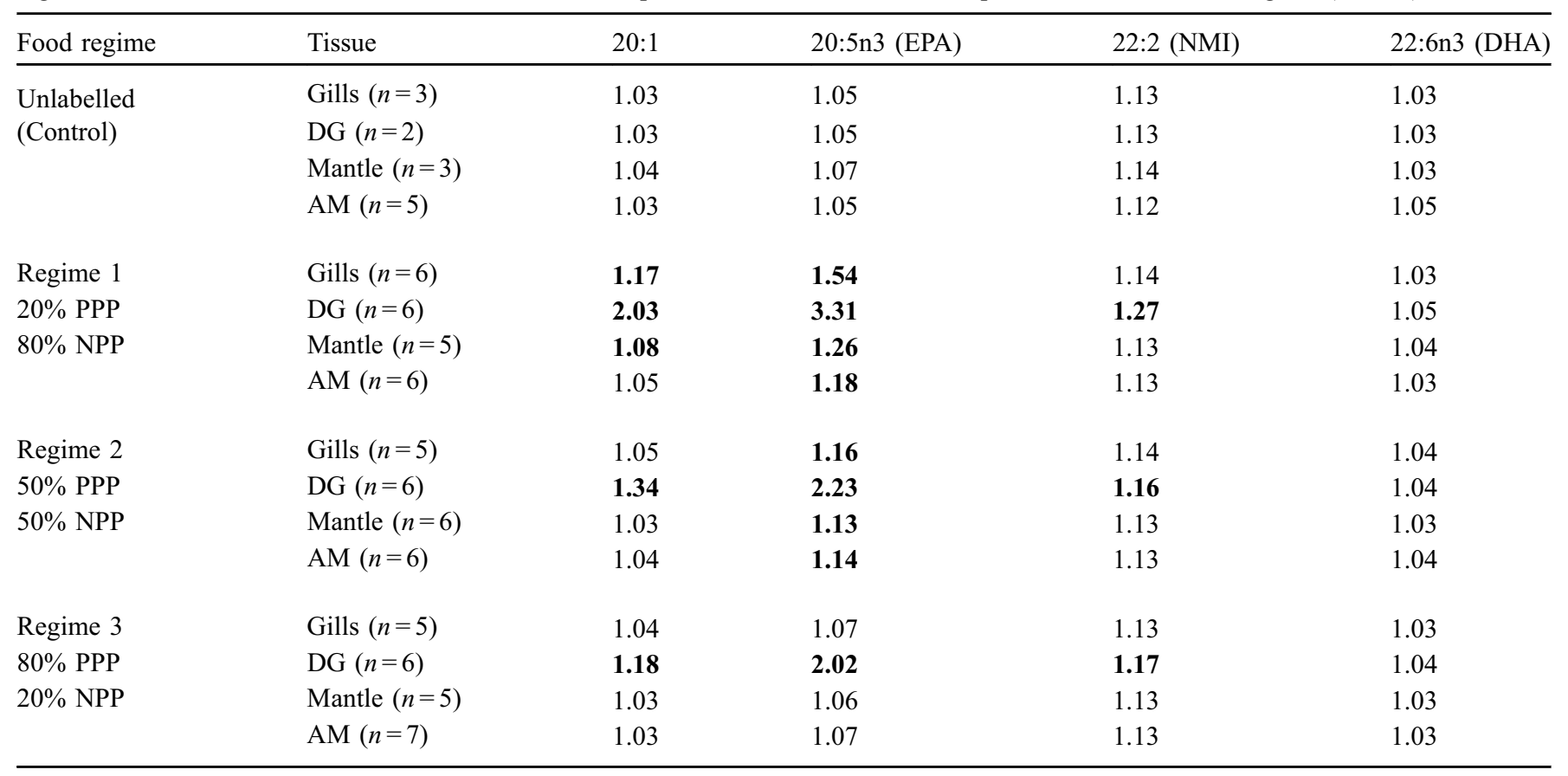

relation reinforces our inference that food availability in the surface layers of water is not a limiting factor for suspended cultured oysters. Such direct link between food availability and bivalve's growth has been demonstrated by Grangeré et al. (2010) in France. During our surveys, we noticed that total FAs in the digestive glands significantly declined in July, which we attributed to the reproductive cycle involving spawning events during the summer. Indeed, the Atlantic Canada region is the most northerly distribution area where $C$. virginica are able to reproduce, with spawning events generally occurring when the water temperature exceeds $20^{\circ} \mathrm{C}$, which is a threshold value that is commonly surpassed in July (Filgueira et al., 2014a). It has been demonstrated that a decrease in EPA (20:503) is namely associated with stressful or energetically expensive situations in bivalves such as gametogenesis and spawning (Stanley and Howard, 1998).

Nano- and pico-sized phytoplankton assemblages are significant global primary producers (Moynihan et al., 2016). Bivalves exhibit high degrees of trophic plasticity, retaining a large amount of food from other sources of different sizes (Cresson et al., 2016). Our study showed that $C$. virginica retains PPP cells and further assimilates its carbon in its tissues. To our knowledge, this study was the first to use isotopically $\left({ }^{13} \mathrm{C}\right)$ labelled PPP to confirm its assimilation by Eastern oysters. Results suggest that PPP's carbon constitutes a food source assimilated sometimes through biosynthesis processes such as the production of NMI (22:2), which is intrinsic to mollusks. Noticeable amounts of NMI have been reported in Mytilidae (M. edulis, 4.6\%) (Paradis and Ackman, 1977) and Ostreidae (C. virginica, 5.8\%) (Paradis and Ackman, 1975). Using M. edulis Zhukova (1991) showed that NMI is one of the only polyunsaturated acids synthesized by marine mollusks. Monoenoic acids, such as 20:1, are present in significant quantities in mollusks (Ackman et al., 1971) and are precursors of NMI (Zhukova and Svetashev, 1986). The complex biosynthesis of NMI (22:2) FAs is de novo (Pogoda et al., 2013) and resumed by the desaturation of 16:0 and 18:0 to produce $16: 1 \omega 7$ and $18: 1 \omega 9$. Followed by

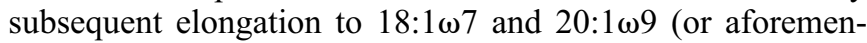
tioned 20:1), further desaturation to $18: 2$ and 20:2, and a final elongation for the production of 20:2 and 22:2 (NMI) (Monroig et al., 2013). Therefore, complex use of PPP carbon was clearly demonstrated through the production of isotopically $\left({ }^{13} \mathrm{C}\right)$ labelled NMI. No statistical analysis was performed for the enrichment results of the experimental regimes because feeding ( 3 days) and fasting ( 3 days) periods during the feeding trials might act as an artefact. Enrichment rates may vary between experimental regimes and longer digestion times could be appropriate in the future. This study PPP assimilation trials focused on four major fatty acids; one NMI precursor (20:1), the 22:2 NMI, EPA, and DHA. EPA is a typical marine PUFA. Both EPA and DHA are important and conservative elements of bio-membranes (Pogoda et al., 2013). DHA is resistant to pressure changes, allowing it to function independently of a fluctuating environment (Rabinovich and Ripatti, 1991). However, Pernet et al. (2007) demonstrated that DHA is sensitive to temperature notably during early stages of warming where bivalves, such as $M$. edulis and $C$. virginica, experience a remodelling of membrane phospholipids.

Picophytoplankton abundance increases from spring to summer in temperate areas, when nutrient concentrations decrease and the system switches from "new" to "regenerated" production and when water temperature reaches its annual maximum (Caroppo, 2000). Major classes of PPP have been presented as Prasinophyceae (division Chlorophyta), Pelagophyceae (division Heterokontophyta) and Prymnesiophyceae 
in numerous marine systems (Thomsen and Buck, 1998; Moon-van der Staay et al., 2000). Smaller phytoplankton like PPP, tends to have a preference for dissolved ammonium, while their nitrate uptake is positively related to cell size (Stolte et al., 1994). In relation to bivalve aquaculture, Mugg Pietros and Rice (2003) hypothesized that ammonia generated by oysters is utilized by rapidly regenerating phytoplankton in the water column, such as PPP. Potential picoeukaryote biomarkers have been demonstrated recently by Moynihan

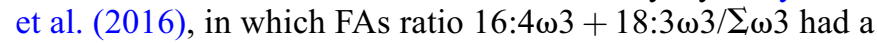
strong correlation with cells abundance. Our study did not assess $16: 4 \omega 3$, as we could not use this recently developed PPP biomarker. However, before the current study, knowledge was limited on PPP species assimilation by mature or commercially sized oysters. The PPP:NPP biomass ratios $(20 \%, 50 \%$ and $80 \%)$ used in the retention efficiency trials are representative of the Foxley system as shown from field data in Figure 2. Similar ratios were also reported by Sonier et al. (2016) in a mussel culture bay in PEI. A number of natural processes might contribute to the capacity of bivalves to capture and ingest PPP cells. In fact, Kach and Ward (2008) showed that aggregation significantly enhances $C$. virginica ingestion of pico-sized particles such as 0.5 and $1 \mu \mathrm{m}$ fluorescent beads, as well as bacteria (greatest cell dimension of $0.6 \mu \mathrm{m}$ ). If bivalves could ingest all particles in an aggregate, they would be able to access a highly concentrated, rapidly sinking source of picoplankton that could represent an important food source (Waite et al., 2000). Flocculation or aggregation might partly explain differential RE values on PPP in our study, showing higher retention in the regime with the lowest PPP cell availability. In the natural environment, particle agglomeration is enhanced by the presence of transparent exopolymeric particles (TEP) that are formed from mucopolysaccharides, which are released in abundance by bacteria, phytoplankton, and benthic suspension-feeders (Li et al., 2008). Other confounding factors also exist, such as surface charge and wettability of particles in suspension (Rosa et al., 2013) and chemical interactions between lectins in the mucus of the pallial organs and carbohydrates present on the surface of microalgal cells (Pales Espinosa et al., 2009). The exact mechanisms used by suspension-feeding bivalves to determine which particles are ingested and which are rejected as pseudo-faeces, however, have yet to be elucidated (Rosa et al., 2013). In the context of shellfish aquaculture, especially in modelling exercises and sustainable aquaculture research, it is important to have reliable data on feeding capabilities and rates of cultured bivalves on available food sources including PPP (Sonier et al., 2016).

\section{Conclusions}

Our study provided important information on the preferred food sources of oysters cultured on the bottom and in suspension. Stable isotope analyses confirmed that all oysters mainly feed on pelagic resources, such as particulate organic matter (POM). FA biomarker methods confirmed that lipid reserves were mostly associated with microalgal sources, but also showed that oysters cultured in suspension have more total FAs in their digestive glands compared to those cultured on the bottom. Further analysis using specific FAs allowed us to infer that, regardless of the culture method used, oysters may feed mainly on dinoflagellates, with minimal contribution from diatoms. While not dominant, biomarkers associated to terrestrial (vascular) plants (which include marine plants) were also detected, and might minimally contribute to the diet of oysters. Discrepancies between analytical methods (stable isotopes and fatty acids profiles) were observed and should be addressed and verified when used in parallel in food web research. Over the course of this study, PPP and NPP biomass differed significantly along the ice-free period when the PPP fraction usually dominates the autotrophic biomass of the Foxley River system (PEI). Through controlled experiments, independent of the micro algal tested treatments, $C$. virginica showed high RE on PPP ( $N$. oculata) and NPP (T. lutea) species, with ranges of $71.8-92.1 \%$ and $92.9-99.1 \%$, respectively. Unexpectedly, the RE of PPP in oysters increased when the availability of PPP was low when compared to a regime with $80 \%$ PPP biomass. We suggest that flocculation or aggregation processes between $N$. oculata and T. lutea explain these results. Through labelling experiments on pico-sized algae, we demonstrated that mature $C$. virginica assimilate PPP as a food source by incorporating carbon into all the sampled tissues (digestive gland, gills, mantle, and abductor muscle). Our work also confirms that carbon from ingested PPP cells is used in an internal biosynthesis process, possibly by the elongation and desaturation of the precursor 20:1 into the final NMI (22:2) (Da Costa et al., 2015), based on the isotopic enrichment of 22:2 (NMI) FA in the digestive glands after the PPP assimilation trials. While further experiments are needed, especially in the field context, our study advanced our knowledge on the feeding physiology of the Eastern oyster (C. virginica). This information is important in the context of aquaculture production, particularly to establish the carrying capacity in coastal ecosystems.

Acknowledgments. This project was funded by the Department of Fisheries and Oceans Canada Program for Aquaculture Regulatory Research (PARR project 2012-G-05). The authors thank Mr. Mathieu Babin (Institut des Sciences de la Mer, Rimouski, QC, Canada) and Dr. Bertrand Genard (Isobiokem, Rimouski, QC, Canada) for providing expertise on fatty acid analysis and for producing isotopically labelled microalgae, respectively. We also thank the many DFO colleagues, field technicians, and laboratory personnel from ISMER. The authors also thank Ms. Angeline LeBlanc for providing statistical input. This work was also performed in the framework of the International Laboratory BeBEST (LIAINEE/UQAR) funded by the Institut des Sciences de la Mer de Rimouski (UQAR, Quebec) and the Institut Environnement Ecologie (CNRS, France).

\section{References}

Ackman RG. WCOT (capillary) gas-liquid chromatography, in: R.J. Hamilton, J.B. Rossell (Eds.), Analysis of oils and fats, Elsevier, New York, 1986, pp. 137-206.

Ackman RG, Hooper SN, Ke PJ. 1971. The distribution of saturated and isoprenoid fatty acids in the lipids of three species of molluscs, Littorina littorea, Crassostrea virginica and Venus mercenaria. Comp Biochem Physiol 39B: 579-587. 
Arnold AA, Genard B, Zito F, Tremblay R, Warschawski DE, Marcotte I. 2015. Identification of lipid and saccharide constituents of whole microalgal cells by ${ }^{13} \mathrm{C}$ solid-state NMR. Biochim Biophys Acta 1848: 369-377.

Barillé L, Prou J, Héral M, Bourgrier S. 1993. No influence of food quality, but ration-dependent retention efficiencies in the Japanese oyster Crossostrea gigas. J Exp Mar Biol Ecol 171: 91-106.

Barillé L, Prou J, Héral M, Razet D. 1997. Effects of high natural seston concentrations on the feeding, selection, and absorption of the oyster Crassostrea gigas (Thunberg). J Exp Mar Biol Ecol 212: $149-172$.

Brito AC, Benyoucef I, Jesus B, Brotas V, Gernez P, Mendes CF, Launeau P, Dias MP, Barillé L. 2013. Seasonality of microphytobenthos revealed by remote-sensing in a South European estuary. Cont Shelf Res 66: 83-91.

Budge SM, Parrish CC. 1998. Lipid biogeochemistry of plankton, settling matter and sediments in Trinity Bay, Newfoundland. II. Fatty acids. Org Geochem 29: 1547-1559.

Cabrol J, Winkler G, Tremblay R. 2015. Physiological condition and differential feeding behavior in the cryptic species complex Eurytemora affinis in the St Lawrence estuary. J Plankton Res 37: 372-387.

Caroppo C. 2000. The contribution of picophytoplankton to community structure in a Mediterranean brackish environment. J Plankton Res 22(2): 381-397.

Coen LD, Brumbaugh RD, Bushek D, Grizzle R, Luckenbach MW, Posey MH, Powers SP, Tolley SG. 2007. Ecosystem services related to oyster restoration. Mar Ecol Prog Ser 341: 303-307.

Cognie B, Barillé L, Rincé Y. 2001. Selective feeding of the oyster Crassostrea gigas fed on a natural microphytobenthos assemblage. Estuaries 24(1): 126-131.

Comeau LA. 2013. Suspended versus bottom oyster culture in eastern Canada: comparing stocking densities and clearance rates. Aquaculture 410-411: 57-65.

Comeau LA, Filgueira R, Guyondet T, Sonier R. 2015. The impact of invasive tunicates on the demand for phytoplankton in longline mussel farms. Aquaculture 441: 95-105.

Cranford PJ, Hargrave BT, Doucette LI. 2009. Benthic organic enrichment from suspended mussel (Mytilus edulis) culture in Prince Edward Island, Canada. Aquaculture 292: 189-196.

Cresson P, Ruitton S, Harmelin-Vivien M. 2016. Feeding strategies of co-occuring suspension feeders in an oligotrophic environment. Food Webs 6: 19-28.

Da Costa F, Robert R, Quéré C, Wikfors GH, Soudant P. 2015. Essential fatty acid assimilation and synthesis in larvae of the bivalve Crassostres gigas. Lipids 50: 503-511.

Dalsgaard J, John MS, Kattner G, Müller-Navarra D, Hagen W. 2003. Fatty acid trophic markers in the pelagic marine environment. $A d v$ Mar Biol 46: 229-352.

Filgueira R, Guyondet T, Comeau LA, Grant J. 2014a. Physiological indices as indicators of ecosystem status in shellfish aquaculture sites. Ecol Indic 39: 134-143.

Filgueira R, Guyondet T, Comeau LA, Grant J. 2014b. A fully-spatial ecosystem-DEB model of oyster (Crassostrea virginica) carrying capacity in the Richibucto Estuary, Eastern Canada. J Mar Syst 136: 42-54.

Filgueira R, Guyondet T, Comeau LA, Tremblay R. 2016. Bivalve aquaculture-environment interactions in the context of climate change. Glob Change Biol. doi:10.1111/gcb.13346.

Fry B. 2007. Stable isotope ecology, 1st edition, Springer, New York, NY, 308 p.

Gaillard B, Meziane T, Tremblay R, Archambault P, Layton KKS, Martel AL, Olivier F. 2015, Dietary tracers in Bathyarca glacialis from contrasting trophic regions in the Canadian Arctic. Mar Ecol Prog Ser 536: 175-186.

Gaillard B, Meziane T, Tremblay R, Archambault P, Blicher ME, Chauvaud L, Rysgard S, Olivier F. 2017. Food resources of the bivalve Astarte elliptica in a sub-Arctic fjord: a multi-biomarker approach. Mar Ecol Prog Ser 567: 139-156

Galloway AWE, Winder M. 2015. Partitioning the relative importance of phylogeny and environmental conditions on phytoplankton fatty acids. PLos ONE 10: e0130053.

Grangeré K, Lefebvre S, Bacher C, Cugier P, Ménesguen A. 2010. Modelling the spatial heterogeneity of ecological processes in an intertidal estuarine bay: dynamic interactions between bivalves and phytoplankton. Mar Ecol Prog Ser 415: 141-158.

Guyondet T, Sonier R, Comeau LA. 2013. Spatially explicit seston depletion index to optimize shellfish culture. Aquac Environ Interact 4: 175-186.

Kach DJ, Ward JE. 2008. The role of marine aggregates in the ingestion of picoplankton-size particles by suspension-feeding molluscs. Mar Biol 153: 797-805.

Kelly JR, Scheibling RE. 2012. Fatty acids as dietary tracers in benthic food webs. Mar Ecol Prog Ser 446: 1-22.

Kirkham AP, Lepère C, Jardillier LE, Not F, Bouman H, Mead A, Scanlan DJ. 2013. A global perspective on marine photosynthetic picoeukaryotes community structure. ISME J 7: 922-936.

Lepage G, Roy CC. 1984. Improved recovery of fatty acid through direct transesterification without prior extraction or purification. $J$ Lipid Res 25(12): 1391-1396.

Li B, Ward JE, Holohan BA. 2008. Transparent exopolymer particles (TEP) from marine suspension feeders enhance particle aggregation. Mar Ecol Prog Ser 357: 67-77.

Loosanoff VL. 1958. Some aspects of behavior of oysters at different temperatures. Biol Bull 114(1): 57-70.

Lowe AT, Galloway AWE, Yeung JS, Dethier MN, Duggins DO. 2014. Broad sampling and diverse biomarkers allow characterization of nearshore organic matter. Oikos 123: 1341-1354.

Møhlenberg F, Riisgård HU. 1978. Efficiency of particle retention in 13 species of suspension feeding bivalves. Ophelia 17: 239-246.

Monroig O, Tocher DR, Navarro JC. 2013. Biosynthesis of polyunsaturated fatty acids in marine invertebrates: recent advances in molecular mechanisms. Mar Drugs 11: 3998-4018.

Moon-van der Staay SY, van der Staay GWM, Guillou L, Vaulot D, Claustre H, Medlin LK. 2000. Abundance and diversity of Prumnesiophytes in the picoplankton community from the equatorial Pacific Ocean inferred from 18S rDNA sequences. Limnol Oceanogr 45: 98-109.

Moynihan M, Barbier P, Olivier F, Toupoint N, Meziane T. 2016. Spatial and temporal dynamics of nano- and pico-size particulate organic matter (POM) in a coastal megatidal system. Limnol Oceanogr. doi:10.1002/lno.10276.

Mugg Pietros J, Rice MA. 2003. The impacts of aquacultured oysters, Crassostrea virginica (Gmelin, 1791) on water column nitrogen and sedimentation: results of a mesocosm study. Aquaculture 220: 407-422.

Newell RIE. 2004. Ecosystem influences of natural and cultivated populations of suspension-feeding bivalves molluscs: a review. $J$ Shellfish Res 23: 51-61.

Pales Espinosa E, Perrigault M, Ward JE, Shumway SE, Allam B. 2009. Lectins associated with the feeding organs of the oyster Crassostrea virginica can mediate particle selection. Biol Bull 217: $130-141$.

Paradis M, Ackman RG. 1975. Occurrence and chemical structure of nonmethylene-interrupted dienioc fatty acids in American oysters, Crasssostrea virginica. Lipids 10: 12-16. 
Paradis M, Ackman RG. 1977. Potential for employing the distribution of anomalous nonmethylene-interrupted dienioc fatty acids in several marine invertebrates as part of food web studies. Lipids 12: 170-176.

Parrish CC. 2013. Lipids in marine ecosystems. Int Sch Res Not Oceanogr 2013: 604045.

Parrish CC. Determination of total lipid, lipid classes, and fatty acids in aquatic samples. in: M.T. Arts, B.C. Wainman (Eds.), Lipids in fresh-water ecosystems, Springer-Verlag, New York, USA, 1999, pp. 5-20.

Parrish CC, McKenzie CH, MacDonald BA, Hatfield EA. 1995. Seasonal studies of seston lipids in relation to microplankton species composition and scallop growth in South Broad Cove, Newfoundland. Mar Ecol Prog Ser 129: 151-164.

Péquin B, Mohit V, Poisot T, Tremblay R, Lovejoy C. 2017. Wind drives microbial eukaryote communities in a temperate closed lagoon. Aquat Mircrob Ecol 78: 187-200.

Perez V, Olivier F, Tremblay R, Neumier U, Thébault J, Chauvaud L, Meziane T. 2013. Trophic resources of the bivalve, Venus verrucosa, in the Chausey archipelago (Normandy, France) determined by stable isotopes and fatty acids. Aquat Living Resour 26: 229-239.

Pernet F, Malet N, Pastoureaud A, Vaquer A, Quéré C, Dubroca L. 2012. Marine diatoms sustain growth of bivalves in a Mediterranean lagoon. J Sea Res 68: 20-32.

Pernet F, Tremblay R, Comeau L, Guderley H. 2007. Temperature adaptation in two bivalve species from different thermal habitats: energetics and remodeling of membrane lipids. J Exp Biol 210: 2999-3014.

Peterson BJ, Fry B. 1987. Stable isotopes in ecosystem studies. Annu Rev Ecol Syst 18: 293-320.

Pogoda B, Buck BH, Saborowski R, Hagen W. 2013. Biochemical and elemental composition of the offshore-cultivated oysters Ostrea edulis and Crassostrea gigas. Aquaculture 400-401: 53-60.

Post DM. 2002. Using stable isotopes to estimate trophic position: models, methods, and assumptions. Ecology 83: 703-718.

Prins TC, Smaal AC, Dame RF. 1998. A review of the feedbacks between bivalve grazing and ecosystem processes. Aquat Ecol 31: 349-359.

Prins TC, Smaal AC, Pouwer AJ. 1991. Selective ingestion of phytoplankton by the bivalves Mytilus edulis L. and Cerastoderma edule (L.). Hydrobiol Bull 25: 93-100.

$\mathrm{R}$ Core Team. R: a language and environmental for statistical computing, R Foundation for Statistical Computing, Vienna, Austria, 2013. http://www.R-project.org/.

Rabinovich AL, Ripatti PO. 1991. On the conformational, physical properties and functions of polyunsaturated acyl chains. Biochim Biophys Acta 1085(1): 53-62.

Richardson TL, Jackson GA. 2007. Small phytoplankton and carbon export from the surface ocean. Science 315: 838-840.

Riisgård HU. 1988. Efficiency of particle retention and filtration-rate in 6 species of northeast American bivalves. Mar Ecol Prog Ser 45: 217-223.
Rosa M, Ward JE, Shumway SE, Wikfors GH, Pales-Espinosa E, Allam B. 2013. Effects of particle surface properties on feeding selectivity in the eastern oyster Crassostrea virginica and the blue mussel Mytilus edulis. J Exp Mar Biol Ecol 446: 320-327.

Seychelles LH, Audet C, Tremblay R, Fournier R, Pernet F. 2009. Essential fatty acid enrichment of cultured rotifers (Brachionus plicatilis, Müller) using frozen-concentrated microalgae. Aquac Nutr 15: 731-439.

Shumway SE, Cucci TL, Newell RC, Yentsch CM. 1985. Particle selection, ingestion, and absorption in filter-feeding bivalves. J Exp Mar Biol Ecol 91: 77-92.

Sonier R, Filgueira R, Guyondet T, Tremblay R, Olivier F, Meziane T, Starr M, LeBlanc AR, Comeau LA. 2016. Picophytoplankton contribution to Mytilus edulis growth in an intensive culture environment. Mar Biol 163: 73.

Søreide JE, Falk-Petersen S, Hegseth EN, Hop H, Carroll ML, Hobson KA, Blachoviak-Samolyk K. 2008. Seasonal feeding strategies of Calanus in the high-Arctic Svalbard region. Deep-Sea Res II 55: 2225-2244.

Spilmont N, Seuront L, Meziane T, Welsh DT. 2011. There's more to the picture than meets the eye: sampling microphytobenthos in a heterogeneous environment. Estuar Coast Shelf Sci 95(4): 470-476.

Stanley D, Howard R. 1998. The biology of prostaglandins and related eicosanoids in invertebrates: cellular, organismal and ecological actions. Am Zool 38: 369-381.

Stolte W, Mccollin T, Noordeloos AAM, Riegman R. 1994. Effects of nitrogen source on the size distribution within marine phytoplankton populations. J Exp Mar Biol Ecol 184: 83-97.

Strohmeier T, Strand Ø, Alunno-Bruscia M, Duinker A, Cranford PJ. 2012. Variability in particle retention efficiency by the mussel Mytilus edulis. J Exp Mar Biol Ecol 412: 96-102.

Thomsen HA, Buck KR. 1998. Nanoflagellates of the central California waters: taxonomy, biogeography and abundance of primitive, green flagellates (Pedinophyceae, Prasinophyceae). Deep Sea Res II 45: 1687-1707.

Trottet A, Roy S, Tamigneaux E, Lovejoy C, Tremblay R. 2008. Impact of suspended mussels (Mytilus edulis L.) on plankton communities in a Magdalen Islands lagoon (Québec, Canada): a mesocosm approach. J Exp Mar Biol Ecol 365: 103-115.

Underwood GJC, Kromkamp J. 1999. Primary production by phytoplankton and microphytobenthos in estuaries. Adv Ecol Res 29: 93-153.

Waite AM, Safi KA, Hall JA, Nodder SD. 2000. Mass sedimentation of picoplankton embedded in organic aggregates. Limnol Oceangr 45: 87-97.

Ward JE, Shumway SE. 2004. Separating the grain from the chaff: particle selection in suspension- and deposit-feeding bivalves. J Exp Mar Biol Ecol 300: 83-130.

Zhukova NV. 1991. The pathway of the biosynthesis of nonmethylene-interrupted dienoic fatty acids in molluscs. Comp Biochem Physiol 100B(4): 801-804.

Zhukova NV, Svetashev VI. 1986. Non-methylene-interrupted dienoic fatty acids in molluscs from the sea of Japan. Comp Biochem Physiol 83B(3): 643-646.

Cite this article as: Sonier R, Tremblay R, Olivier F, Meziane T, Comeau LA. 2017. Cultured eastern oysters (Crassostrea virginica): retention and assimilation of picophytoplankton using a multi-biomarker approach. Aquat. Living Resour. 30: 31 